JOTE Volume 2 Nomor 1 Tahun 2020 Halaman 239-246 JOURNAL ON TEACHER EDUCATION Research \& Learning in Faculty of Education

\title{
PENINGKATAN KEMAMPUAN MENULIS KARANGAN DESKRIPSI DENGAN METODE PEMBELAJARAN FIELD TRIP
}

\author{
Sri Sanita ${ }^{1}$, Rusdial Marta ${ }^{2}$, Nurhaswinda ${ }^{3}$ \\ SI PGSD, Fakultas IImu Pendidikan, Universitas Pahlawan Tuanku Tambusai \\ srisanita434@gmail.com
}

\begin{abstract}
Abstrak
Salah satu solusi untuk mengatasi masalah ini dengan menggunakan metode field trip. Tujuan penelitian ini mendeskripsikan peningkatan hasil belajar Bahasa Indonesia materi menulis karangan deskripsi. Metode ini adalah Penelitian Tindakan Kelas (PTK) yang dilaksanakan dalam dua siklus. Setiap siklus terdiri dari dua pertemuan dan empat tahap, yaitu perencanaan, pelaksanaan, observasi, refleksi. dan waktu penelitian dilaksanakan mulai bulan Juli hingga Agustus 2020. Subjek penelitian ini siswa kelas IV yang berjumlah 16 orang siswa. Teknik pengumpulan data berupa wawancara, dokumentasi, observasi dan tes. Hasil penelitian ini dapat disimpulkan bahwa hasil belajar siswa materi menulis karangan deskripsi kelas IV SD Tahfizh Qudwatuna, pada siklus I dan siklus II menunjukkan diantaranya sebelum dilakukan tindakan rata-rata siswa 67,1 . Pada siklus I rata-rata siswa meningkat menjadi 73,7. Pada siklus II ratarata siswa semakin meningkat menjadi 80,1 . Dari hasil ini menunjukkan bahwa pembelajaran menggunakan metode field trip
\end{abstract}

Kata kunci: Karangan Deskripsi, Metode Field Trip, Siswa Sekolah Dasar

\begin{abstract}
One solution to solve this problem is by using the field trip method. The purpose of this research is to describe the improvement of Indonesian learning outcomes in writing descriptive essays. This method is a Classroom Action Research (CAR) which is carried out in two cycles. Each cycle consists of two meetings and four stages, namely planning, implementing, observing, reflecting. and the time of the research was carried out from July to August 2020. The subjects of this study were 16 grade students. Data collection techniques in the form of interviews, documentation, observation and tests. The results of this study can be concluded that the results of student learning material writing essays description class IV SD Tahfizh Qudwatuna, in cycle I and cycle II showed that before the action was taken the average student was 67.1. In the first cycle the students' average increased to 73.7. In the second cycle the student average increased to 80.1. From these results indicate that learning uses the field trip method
\end{abstract}

Keywords: Essay Description, Field Trip Method, Elementary School Students 


\section{PENDAHULUAN}

Menulis menurut kamus lengkap bahasa Indonesia adalah berasal dari kata tulis. Tulis adalah ada huruf (angka dan sebagainya) yang dibuat (digurat dan sebagainya) dengan pena (pensil, cat, dan sebagainya). Keterampilan menulis dalam pembelajaran adalah suatu hal yang penting. Hal ini seperti yang ungkap oleh Tarigan (2008:3) bahwa keterampilan menulis berfungsi sebagai alat komunikasi secara tidak langsung, tidak secara tatap muka dengan orang lain. Dalam kegiatan menulis ini, penulis harus terampil memanfaatkan grafologi, struktur bahasa dan kosa kata. Selain itu, keterampilan menulis ini tidak akan datang secara otomatis, tetapi harus melalui latihan dan praktik yang banyak dan teratur.

Istilah karangan deskripsi berasal dari kata "karangan" dan "deskripsi”. Kata karangan didefinisikan sebagai hasil mengarang; tulisan; cerita; artikel; buah pena. Karangan juga berarti ciptaan; gubahan (lagu, musik, nyanyian). Karangan juga dinyatakan sebagai cerita yang mengada-ada (yang dibuat-buat) maupun hasil rangkaian atau susunan (Tim Penyusun Kamus Pusat Bahasa, 2005: 506). Henry Guntur Tarigan (2008: 21) menyatakan, karangan merupakan pikiran atau gagasan yang disampaikan kepada orang lain dalam bahasa tulis.

Kata deskripsi didefinisikan sebagai pemaparan atau penggambaran dengan kata-kata secara jelas dan terperinci serta uraian (Tim Penyusun Kamus Pusat Bahasa, 2005: 258). Titik Maryuni (2007: 11) menjelaskan, karangan deskripsi adalah karangan yang melukiskan, menggambarkan, memerikan suatu peristiwa atau objek hasil penginderaan dengan sehidup-hidupnya dan disertai data-data yang kuat sehingga pembaca merasa seolah-olah terlibat di dalamnya secara langsung.

Menurut Keraf (dalam Nely, 2010: 21) karangan deskripsi atau pemerian merupakan sebuah bentuk tulisan yang bertalian dengan usaha para penulisuntuk memberikan perincian dari objek yang dibicarakan. Pendapat lain menjelaskan bahwa deskripsi adalah tulisan atau karangan yang mengajak para pembaca bersama-sama menikmati, merasakan memahami dengan sebaikbaiknya beberapa objek (sasaran, maksud), adegan, kegiatan, ruang (pribadi, oknum) atau suasana hati yang telah dialami penulis (Tarigan dalam Nely, 2010: 22). Pendapat serupa dikemukakan oleh Sujanto (dalam Sulistiowati, 2008: 24). Deskripsi adalah paparan tentang suatu persepsi yang ditangkap oleh pancaindera. Kita melihat, mendengar, mencium, dan merasakan melalui alatalat indera kita. Dengan suatu kata, kita mencoba melukiskan apa-apa yang kita tangkap dengan pancaindera itu agar dapat dihayati oleh orang lain.

Salah satu hal positif yang dapat ditimbulkan oleh anak dalam menulis adalah, setiap anak dapat merimajinasi dan menggambarkan beberapa cerita dalam bentuk karangan, sesuai dengan apa yang ada dipikiran anak tersebut. Banyak bentuk karangan yang bisa dikembangkan oleh anak antara lain adalah karangan deskripsi, karangan narasi dan karangan argumentasi.

Menulis karangan deskripsi adalah salah satu keterampilan bidang sastra yang harus dikuasai oleh siswa kelas empat. Pembelajaran menulis karangan bertujuan untuk meningkatkan kemampuan siswa dalam menulis karya sastra, 
khususnya karangan deskripsi. Keterampilan menulis ini perlu ditanamkan kepada siswa di Sekolah Dasar, sehingga siswa mempunyai kemampuan untuk mengimajinasikan cerita dengan baik. Menulis sebuah karangan bukan hanya ditujukan untuk penghayatan dan pemahaman saja, melainkan berpengaruh mempertajam terhadap kepekaan perasaan, penalaran, serta kepekaan anak terhadap masalah kemanusiaan. Kemampuan tersebut ditentukan oleh beberapa faktor penting dalam proses pembelajaran menulis karangan deskripsi.

Penelitian ini didasarkan pada permasalahan siswa sekolah dasar yang terjadi pada proses pembelajaran menulis karangan deskripsi ini. Setelah peneliti melakukan observasi secara langsung maka didapat tidak adanya kegiatan pembelajaran yang memotivasi siswa untuk lebih bersemangat dalam pembelajaran menulis. Siswa masih merasa kesulitan untuk menuangkan apa yang perlu ditulis. Siswa juga cenderung kebingungan memulai dari mana apa yang akan ditulisnya. Pada awal pembelajaran guru hanya menerangkan materi secara verbal dan langsung meminta siswa untuk menulis dengan acuan buku paket tanpa menggunakan objek nyata. Materi dianggap sulit sehingga siswa sekedar menulis tanpa memerhatikan komponen lainnya seperti ejaan, huruf kapital, dan keruntutan kalimat. Banyak dari mereka tidak dapat menulis karangan deskripsi secara baik dan benar. Sebagai contoh dari beberapa anak yang mengerjakan, mereka belum bisa menerapkan objek dari pembicaraan diperoleh melalui pengamatan bentuk secara teliti, selain itu sebagian dari anak juga mengutamakan logika dalam menulis karangan dari pada perasaan. Hal ini sangat berpengaruh terhadap eksistensi dari setiap karangan yang di buat.

Permasalahan diatas peneliti akan melakukan suatu penelitian dengan menggunakan metode pembelajaran Field trip, dimana nantinya diharapkan anak dapat meningkatkan kualitas disetiap karangan yang mereka tulis. Metode Field Trip ini adalah metode dengan cara mengajar yang dilaksanakan dengan mengajak siswa ke suatu tempat atau obyek tertentu di luar sekolah untuk mempelajari atau menyelidiki sesuatu seperti meninjau lingkungan sekitar, taman, peternakan, perkebunan, lapangan bermain dan sebagainya.

Berdasarkan dari permasalahan diatas, maka penulis ingin melakukan penelitian dengan judul Peningkatan Kemampuan Menulis Karangan Deskripsi Dengan Metode Pembelajaran Field Tri.

\section{METODE}

Penelitian ini akan dilaksanakan di kelas IV SD Tahfizh Qudwatuna. Dengan adanya penelitian ini tentang meningkatkan kemampuan menulis karangan deskripsi dengan metode pembelajaran field trip, diharapkan dapat menjadi pembelajaran yang tidak membosankan bagi siswa. penelitian Penelitian Tindakan Kelas (PTK) adalah siswa dan siswi kelas IV SD Tahfizh Qudwatuna yang berjumlah 16 orang siswa, yang terdiri dari 12 orang laki-laki dan 4 orang perempuan. Peneliti mengambil subjek penelitian di kelas karena permasalahan kemampuan siswa belajar menulis karangan deskripsi terjadi pada siswa dan siswi kelas IV SD Tahfizh Qudwatuna.

Jenis penelitian ini adalah menggunakan penelitian tindakan kelas (PTK). Penelitian tindakan kelas merupakan penelitian yang dilakukan oleh guru yang subjeknya seluruh siswa didalam kelas tersebut dengan tujuan untuk memperbaiki atau meningkatkan proses 
pembelajaraan (Marta, R, 2018:82). Penelitian dilakukan dengan jalan merancang, melaksanakan dan merefleksikan tindakan secara kolaboratif dan partisipatif yang bertujuan untuk memperbaiki proses pembelajaran di kelas melalui suatu tindakan dalam suatu siklus (Fadhilaturrahmi, 2017a).

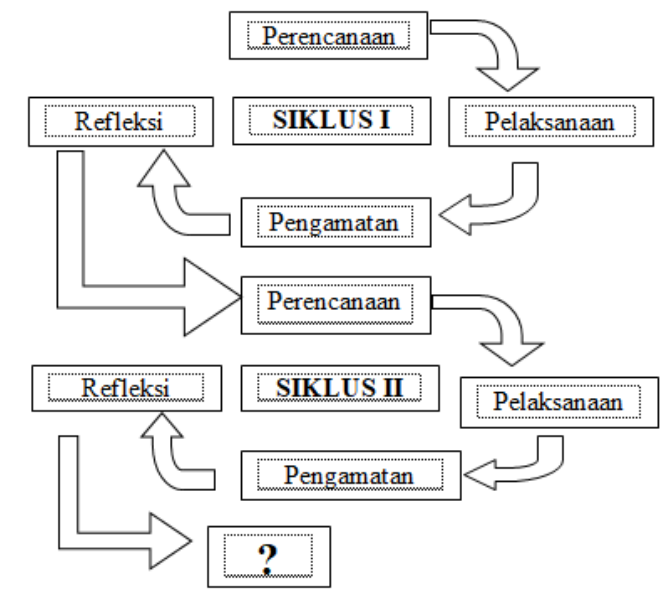

Gambar 3.1.

Siklus Penelitian Tindakan Kelas (PTK)

(Arikunto, 2010:137)

\section{PEMBAHASAN}

\section{Pratindakan}

Sebelum melakukan penelitian, peneliti melakukan studi awal dalam permasalahan yang dilakukan dengan wawancaran observasi. Berdasarkan hasil observasi ditemukan suatu permasalahn khususnya dalam menulis karangan deskripsi yang terjadi dikeleas IV.

Hal ini terlihat dari nilai rata-rata siswa keseluruhan baru mencapai 67,1. Nilai rata-rata tersebut masih berada di bawah kriteria ketuntasan minimal 75 . Jumlah siswa yang mencapai ketuntasan belajar juga hanya mencapai 5 siswa yaitu $31 \%$. Ketuntasan belajar siswa ini masih belum sesuai dengan dengan kriteria keberhasilan penelitian yaitu $75 \%$. Hasil tes pratindakan hal ini menunjukkan hasil yang kurang optimal. Jumlah siswa yang mencapai keberhasilan dalam penelitian hanya mencapai 5 siswa, dan jumlah yang tidak mencapai keberhasilan dalam penilaian mencapai 11 siswa.

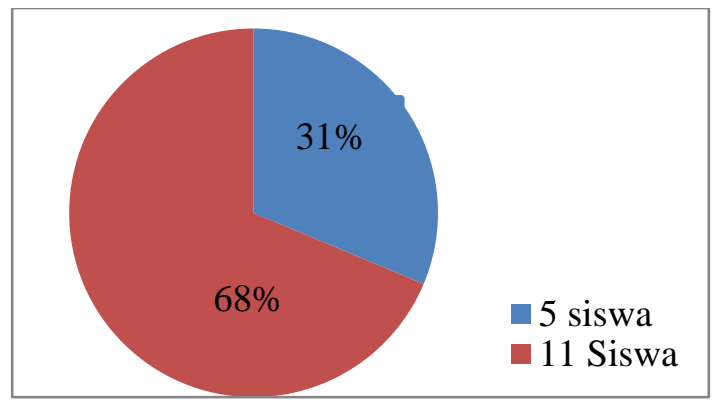

Gambar 4.4

Presentase Hasil Penilaian Siswa Menulis Karangan

Deskripsi Pada Pratindakan 
Masih banyaknya siswa yang belum tuntas untuk menulis karangan deskripsi dan perlu dilakukan upaya untuk meningkatkannya.

\section{Siklus 1}

Hasil tes tindakan siklus I dilakukan terhadap hasil tes menulis karangan deskripsi siswa. Hal itu terlihat dari nilai rata-rata siswa secara keseluruhan sudah mencapai 73,7 . Nilai rata-rata mengalami peningkatan dari kondisi awal 67,1 meningkat menjadi 73,7 . Walaupun nilai rata-rata tersebut masih kurang dari kriteria ketuntasan minimal yaitu 75. Jumlah siswa yang mencapai ketuntasan belajar pada tindakan siklus I telah mencapai 8 siswa yaitu 50\%. Sedangkan siswa yang belum mencapai ketuntasan sekitar 8 siswa yaitu $50 \%$. Jumlah siswa yang mencapai keberhasilan dalam penilaian mencapai 8 siswa. Jumlah yang tidak mencapai keberhasilan dalam penilaian mencapai 8 siswa.

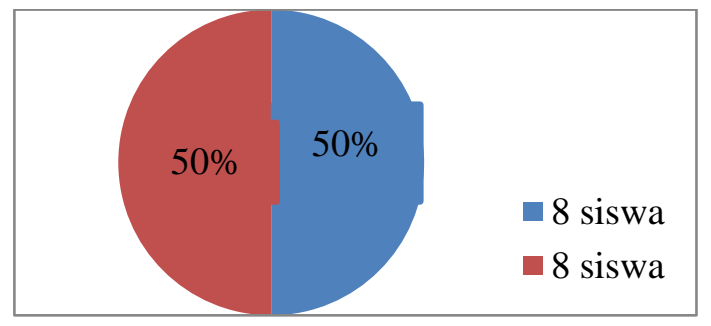

\section{Gambar 4.13}

Presentase Hasil Penilaian Siswa Menulis Karangan Deskripsi Pada Siklus I

Berdasarkan hasil observasi, kendala-kendala yang dialami siswa selama proses menulis karangan deskripsi adalah sebagai berikut: siswa masih kesulitan untuk menentukan tema yang akan ditulis, pemilihan kata yang digunakan siswa masih menggunakan pemilihan kata bahasa sehari-hari, siswa juga masih menulis karangan deskripsi seadanya. Kendala-kendala tersebut harus segera diatasi agar meningkatkan menulis karangan deskripsi siswa dengan menggunakan metode field trip dapat berhasil sesuai rencana.

\section{Siklus II}

Hasil tes tindakan siklus II dilakukan terhadap hasil tes menulis karangan deskripsi siswa. Hal ini terlihat dari nilai rata-rata siswa secara keseluruhan sudah mencapai 80,1. Nilai rata-rata mengalami peningkatan dari siklus I 73,7. Nilai rata-rata tersebut sudah berada diatas kriteria ketuntasan minimal 75 . Jumlah siswa yang meencapai ketuntasan belajar pada tindakan siklus II telah mencapai 12 siswa yaitu 75\%. Jumlah siswa yang mencapai keberhasilan dalam dalam penilaian 12 siswa. Jumlah yang tidak mencapai keberhasilan dalam penilaian mencapai 4 siswa. 


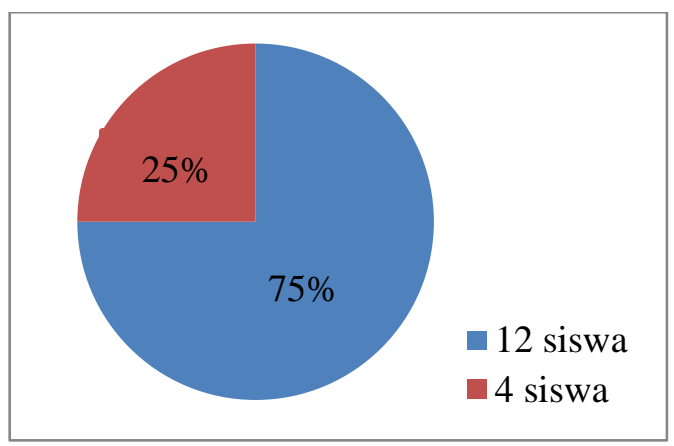

Gambar 4.22

\section{Presentase Hasil Penilaian Siswa Karangan Deskripsi Pada Siklus II}

Berdasarkan hasil observasi, kendala-kendala yang dialami siswa selama proses menulis karangan deskripsi telah dibimbing oleh guru dengan sebaik mungkin. Guru juga merespon pertanyaan-pertanyaan yang diajukan oleh siswa. Aktivitas siswa dalam pembelajaran menulis karangan deskripsi dengan menggunakan metode field trip sudah ada terlihat peningkatan dari segi penulisan, kerapian, sudah lebih baik dari siklus sebelumnya.

Berdasarkan hasil penelitian melalui metode pembelajaran Field Trip Kemampuan Menulis Karangan Deskripsi kelas IV SD Tahfizh Qudwatuna mengalami peningkatan.. Peningkatan Kemampuan Menulis Karangan Deskripsi tersebut dapat di lihat dari perbandingan nilai pratindakan, siklus I, siklus II, pada gambar diagram berikut ini.

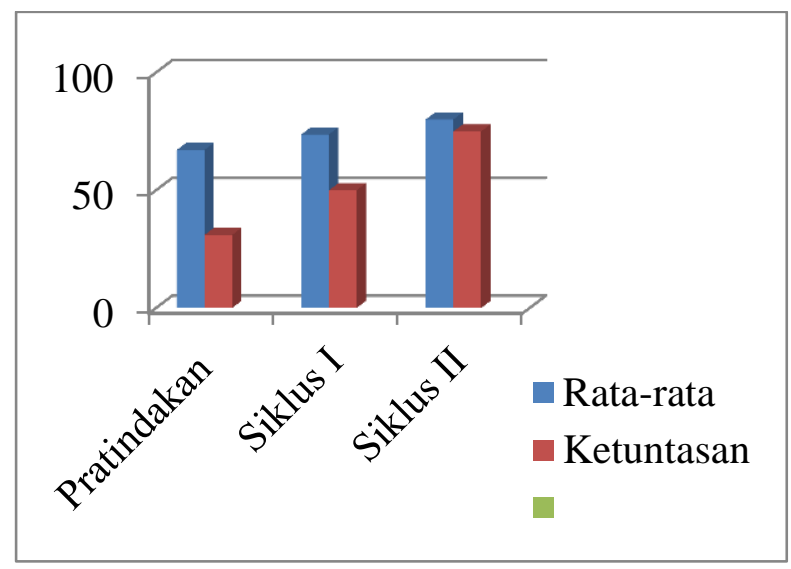

\section{Gambar 4.24}

\section{Peningkatan Nilai Rata-rata dan \% Katuntasan Klasikal Menulis Karangan Deskripsi Pada Pratindakan, Siklus I, dan Siklus II}

Berdasarkan pada gambar 4.24 dapat disimpulkan pada kondisi pratindakan nilai rata-rata ketuntasan siswa sekitar 67,1 dengan presentasenya $31 \%$. Pada siklus I meningkat dari kondisi pratindakan 67,1 menjadi 73,7 dengan presentase $50 \%$. Hasil penelitian pada siklus II telah memenuhi kriteria ketuntasan minimal (KKM) yaitu 75 dengan nilai rata-rata siswa 80,1 dengan presentase $75 \%$.

Peningkatan juga terjadi pada proses pembelajaran yang semakin baik. Keberhasilan proses dalam penelitian ini dapat dilihat dari hasil lembar observasi aktivitas guru dan lembar observasi aktivitas siswa pada msing-masing lampiran. 
Berdasrkan hasil observasi dapat disimpulkan bahwa proses pembelajaran secara keseluruhan sudah cukup baik yang ditunjukkan dengan peningkatan pada lembar observasi yang diamati dari pratindakan, siklus I, dan siklus II.

\section{KESIMPULAN}

Berdasarkan hasil penelitian dan pembahasan dapat disimpulkan bahwa metode field trip sudah dilaksanakan dalam pembelajaran menulis karangan deskripsi siswa kelas IV SD Tahfizh Qudwatuna. Sebelum melaksanakan field trip siswa diberi penjelasan mengenai hal-hal yang harus dilakukan ketika mengunjungi objek yang berada di lingkungan sekitar sekolah, yaitu Musholah dan perpustakaan sekolah untuk melakukan pengamatan. Siswa dibimbing guru menggali informasi dan mencatatnya. Hasil pengamatan didiskusikan didalam kelas, kemudian dituangkan didalam bentuk karangan deskripsi. Karangan deskripsi yang ditulis siswa berisi penggambaran terhadap objek yang diamati ketika melaksanakan field trip dalam pembelajaran menulis karangan deskripsi ini.

Pelaksanaan metode field trip dalam pembelajaran menulis karangan deskripsi siswa kelas IV SD Tahfizh Qudwatuna telah memberikan dampak positif, yaitu terjadi peningkatan terhadap proses pembelajaran. Peningkatan proses dapat dilihat dari perbandingan kondisi proses pembelajaran antara tahap pratindakan, tindakan siklus I, dan tindakan siklus II. Pada tahap pratindakan, siswa tampak pasif dan tidak bergairah untuk mengikuti proses pembelajaran. Pada tindakan siklus I, siswa tampak lebih aktif dan antusias dalam mengikuti proses pembelajaran. Keaktifan dan keantusias siswa lebih meningkat ketika mengikuti proses pembelajaran pada siklus II. Peningkatan dapat dilihat dari perbandingan nilai rata-rata tes menulis karangan deskripsi siswa pratindakan, tindakan siklus I, dan tindakan siklus II. Nilai rata-rata siswa meningkat sebesar 73,7 pada siklus I (kondisi awal 67,1 meningkat menjadi 73,7) dan sebesar 80,1 pada siklus II (kondisi siklus I 73,7 meningkat menjadi 80,1). Ketuntsan belajar siswa meningkat sebesar 8 siswa atau $50 \%$ pada tindakan siklus I (kondisi awal 5 siswa atau $31 \%$ meningkat menjadi 8 siswa atau 50\%) dan sebesar 12 siswa atau 75\% pada siklus II (kondisi siklus I 8 siswa atau 50\% meningkat menjadi 12 siswa atau $75 \%$ )

\section{DAFTAR PUSTAKA}

Aqib, Zainal, dkk. (2011). Penelitian Tindakan Kelas. Bandung: Yrama Widya.

Arikunto Suharsimi. (2012). Dasar-Dasar Evaluasi Pendidikan. Jakarta: Bumi Aksara. JPGSD Volume 01 Nomor 02 Tahun 2012, 0-216.

Burhan Nurgiyantoro. (2012). Penilaian Pembelajaran Bahasa Berbasis Kompetensi. Yogyakarta: BPFE-Yogyakarta.

Fadhilaturrahmi, F. (2017a). Penerapan Pendekatan Saintifik Untuk Meningkatkan Kemampuan Komunikasi Matematik Peserta Didik di 
Sekolah Dasar. EDUHUMANIORA: Jurnal Pendidikan Dasar, 9(2), 109118. https://doi.org/10/17509/EH.V912.7078

Henry Guntur Tarigan. (2008). Menulis Sebagai Suatu Keterampilan Berbahasa. Edisi Revisi. Bandung: Penerbit Angkasa.

Marta, R. (2018). Penerapan Model Kooperatif tipe Nominal Group untuk Meningkatan Hasil Belajar Matematika di Kelas IV Sekolah Dasar. Jurnal Basicedu Volume 2 Nomor 1 Tahun 2018 Halaman 82.

Poerwanti, Endang dkk. (2008). Asesmen Pembelajaran SD. Jakarta: Direktorat Jenderal Pendidikan Tinggi Departemen Pendidikan Nasional.

Sulistiowati.(2008). Skripsi: Model Pembelajaran Menulis Karangan dengan Metode Karya Wisata. Bandung: Universitas Bale Bandung.

Tarigan, H. G. (2008). Menulis sebagai Keterampilan Berbahasa. Bandung: Angkasa.

Tim Penyusun Kamus Pusat Bahasa. (2005). Kamus Besar Bahasa Indonesia. Jakarta: Balai Pustaka.

Titik Maryuni. (2007). Ayo Berlatih Mengarang. Surakarta: CV. Mediatama. 